\title{
PELATIHAN PENGOLAHAN DATA PENELITIAN DENGAN SOFTWARE SPSS BAGI MAHASISWA LINTAS PERGURUAN TINGGI DALAM KABUPATEN ACEH BARAT PROVINSI ACEH
}

\author{
Zainal Putra $^{\text {1) }}$, Ishak Hasan ${ }^{2)}$, Budianto ${ }^{3)}$, Cut Devi Maulidasari ${ }^{4)}$, Syafruddin Chan ${ }^{\text {5) }}$ \\ ${ }^{1,3,4}$ Dosen Universitas Teuku Umar, Meulaboh - Aceh Barat \\ ${ }^{2,5}$ Dosen Universitas Syiah Kuala, Banda Aceh \\ E-mail: zainalputra@utu.ac.id
}

\begin{abstract}
Abstrak
Dari hasil observasi yang kami lakukan, ternyata tidak sedikit mahasiswa menyerahkan pengolahan data penelitiannya kepada penyedia jasa di luar kampus secara ilegal. Namun sangat disayangkan bahwa hasil olahan data yang dilakukan penyedia jasa tersebut banyak terdapat kekeliruan. Hal tersebut dikarenakan si penyedia jasa tidak menguasai teknik dan teori statistik yang mumpuni. Akibatnya hasil pengelolahan data tersebut tidak memenuhi kaidah ilmiah. Fenomena tersebut terjadi karena mahasiswa lebih menyukai budaya instan dalam penyelesaian tugas akhir ketimbang menjalani proses. Dari keprihatian itu, kami mengambil sebuah langkah kongkrit dengan melaksanakan program pengabdian kepada masyarakat dengan tema "Pelatihan Pengelohan Data Penelitian dengan Software SPSS Bagi Mahasiswa Lintas Perguruan Tinggi dalam Kabupaten Aceh Barat Provinsi Aceh. Keterampilan dalam mengoperasikan software SPSS ini sangat penting bagi mahasiswa dalam rangka penyelesaian tugas akhir mereka. Sasaran program ini adalah mahasiswa lintas perguruan tinggi dalam Kabupaten Aceh Barat Provinsi Aceh. Hasil yang dicapai dari program ini adalah: (a). Meningkatnya pengetahuan dan pemahamannya tentang metodologi penelitian, (b). Meningkatnya pengetahuan dan pemahamannya tentang ilmu statistika, dan (c). Memiliki kemampuan dalam mengoperasikan software olah data penelitian, khususnya SPSS.
\end{abstract}

Kata Kunci: Pengolahan Data Penelitian, Software SPSS

\section{PENDAHULUAN}

Dari hasil pengalaman penulis baik sebagai pembimbing skripsi maupun sebagai penguji proposal skripsi serta penguji sidang sarjana, banyak sekali ditemukan mahasiswa yang tidak paham mengenai cara pengolahan data, bahkan terhadap output hasil penelitian yang disajikan dalam laporan juga mereka tidak paham. Hasil observasi yang kami lakukan dan wawancara secara pribadi dengan mahasiswa yang bersangkutan, ternyata kebanyakan mahasiswa menyerahkan pengolahan data penelitiannya kepada pihak penyedia jasa di luar kampus secara ilegal. Namun sangat disayangkan, bahwa hasil olahan data yang dilakukan penyedia jasa banyak terdapat kekeliruan. Hal tersebut dikarenakan si penyedia jasa tidak menguasai teknik dan teori statistik yang mumpuni. Akibatnya hasil pengelolahan data tersebut tidak memenuhi kaidah ilmiah. Yang pada akhirnya akan menyulitkan mahasiswa yang bersangkutan dalam penyelesaian tugas akhir.
Fenomena di atas terjadi karena mahasiswa lebih menyukai budaya instan dalam penyelesaian tugas akhir ketimbang menjalani proses. Kurangnya nilai moral serta etika juga mendorong munculnya perilaku untuk mendapatkan hasil cepat tanpa mau belajar lebih dulu. Termasuk dalam hal ini adalah penguasaan keterampilan yang bersifat teknis.

Dalam pembuatan skripsi misalnya, mahasiswa seringkali memiliki ketakutan dalam hal pengolahan data statistik. Mereka menganggap bahwa pengolahan data statistik merupakan hal yang sulit sehingga sebagian mahasiswa memilih untuk menyerahkan pengolahan data penelitiannya kepada penyedia jasa pengolahan data. Hal ini tentu sangat disayangkan mengingat kemampuan pengolahan data statistik akan mempengaruhi kualitas kemampuan interpretasi hasil dan kualitas karya ilmiah tersebut.

Atas dasar keprihatian itu, kami mengambil sebuah langkah kongkrit dengan melaksanakan program pengabdian kepada masyarakat dengan tema "Pelatihan Pengelohan Data Penelitian dengan Software SPSS Bagi Mahasiswa Lintas Perguruan 
Tinggi Dalam Kabupaten Aceh Barat Provinsi Aceh. Sebagaimana diketahui bahwa keterampilan dalam mengoperasikan software SPSS ini sangat penting bagi mahasiswa dalam rangka penyelesaian tugas akhir mereka.

\section{Permasalahan Mitra dan Solusi yang Ditawarkan}

Dari hasil wawancara dan pengamatan yang kami lakukan, diperoleh informasi bahwa mahasiswa sangat kesulitan dalam mengoperasikan software olah data khususnya software SPSS. Kendala tersebut diperparah karena mahasiswa sangat lemah dalam pemahaman metodologi penelitian serta ilmu statistika.

Secara terperinci permasalahan yang dihadapi oleh mahasiswa meliputi:

a. Masih lemahnya dalam menguasai metodologi penelitian.

b. Belum memiliki kemampuan dalam penguasaan software oleh data, khususnya SPSS.

Untuk mengatasi masalah di atas, kami menawarkan solusi kepada mitra berupa pelatihan pengolahan data penelitan dengan software SPSS bagi mahasiswa lintas perguruan tinggi dalam Kabupaten Aceh Barat Provinsi Aceh.

\section{METODE PELAKSANAAN}

Kegiatan pelatihan ini dilaksanakan dalam dua angkatan. Angkatan pertama diundang sebanyak 28 orang mahasiswa lintas perguruan tinggi (PT) dalam Kabupaten Aceh Barat. Adapun PT yang mahasiswanya diundang sebagaimana disajikan dalam tabel di bawah ini.

Tabel 1. Data Perguruan Tinggi dan Mahasiswa yang Diundang pada Pelatihan Pengolahan Data dengan Software SPSS Angkatan I Tahun 2017

\begin{tabular}{|c|l|c|c|}
\hline NO. & PERGURUAN TINGGI & FAKULTAS & $\begin{array}{c}\text { JUMLAH } \\
\text { MAHASISWA } \\
\text { YANG DIUNDANG }\end{array}$ \\
\hline 1. & Universitas Teuku Umar & Ekonomi & 10 orang \\
\hline 2. & Universitas Teuku Umar & Pertanian & 2 orang \\
\hline 3. & Universitas Teuku Umar & FISIP & 2 orang \\
\hline 4. & Universitas Teuku Umar & FKM & 2 orang \\
\hline 5. & STIMI Meulaboh & - & 4 orang \\
\hline 6. & STAI Tgk. Dirundeng & - & 4 orang \\
\hline 7. & STKI Bina Bangsa Meulaboh & - & 4 orang \\
\hline & \multicolumn{1}{|c|}{ Jumlah } & & 28 orang \\
\hline
\end{tabular}

Sedangkan pada angkatan kedua diundang sebanyak 35 orang mahasiswa lintas perguruan tinggi (PT) dalam Kabupaten Aceh Barat. Adapun PT yang mahasiswanya diundang sebagaimana disajikan dalam tabel di bawah ini.

Tabel 2. Data Perguruan Tinggi dan Mahasiswa yang Diundang pada Pelatihan Pengolahan Data dengan Software SPSS Angkatan II Tahun 2017

\begin{tabular}{|c|c|c|c|}
\hline NO. & PERGURUAN TINGGI & FAKULTAS/ PRODI & $\begin{array}{c}\text { RENCANA JMLAH } \\
\text { MAHASISWA YANG } \\
\text { DIUNDANG }\end{array}$ \\
\hline 1. & Universitas Teuku Umar & Ekonomi & 15 orang \\
\hline 2. & Universitas Teuku Umar & Pertanian & 2 orang \\
\hline 3. & Universitas Teuku Umar & FISIP & 2 orang \\
\hline 4. & Universitas Teuku Umar & FKM & 2 orang \\
\hline 5. & Universitas Teuku Umar & FKM & 2 orang \\
\hline 6. & Universitas Teuku Umar & Prodi S1 Teknik Industri & 2 orang \\
\hline 7. & STIMI Meulaboh & $\cdot$ & 6 orang \\
\hline 8. & STAI Tgk. Dirundeng & $\cdot$ & 2 orang \\
\hline \multirow[t]{2}{*}{9.} & STKIP Bina Bangsa Meulaboh & $\cdot$ & 2 orang \\
\hline & Jumlah & & 35 orang \\
\hline
\end{tabular}

Sebelum pelaksanaan pelatihan, tim kami menyampaikan surat undangan kepada masingmasing pimpinan perguruan tinggi untuk menyampaikan infomasi pelatihan ini kepada masing-masing mahasiswanya. Untuk angkatan I, surat dikirimkan pada tanggal 30 Agustus 2017. Waktu pendaftaran dimulai tanggal 01 s.d. 13 September 2017 (selama 12 hari). Pelatihan angkatan I dilaksanakan hari Sabtu tanggal 16 September 2017, yang bertempat di Gedung Fakultas Ekonomi Universitas Teuku Umar.

Sedankgan angkatan II, surat dikirimkan pada tanggal 11 Desember 2017. Waktu pendaftaran dimulai tanggal 13 s.d. 20 Desember 2017 (selama 8 hari). Pelatihan angkatan II dilaksanakan hari Sabtu tanggal 23 Desember 2017 di tempat yang sama.

Kepada mahasiswa yang berminat dapat mengisi lembar konfirmasi keikutsertaan pada pelatihan ini serta memberikan pas photo ukuran $3 \mathrm{x}$ 4 sebanyak dua lembar. Photo tersebut digunakan/ditempelkan pada lembar konfirmasi sebanyak 1 (satu) lembar dan pada lembar sertifikat pelatihan sebanyak 1 (satu) lembar. Dua hari menjelang pelaksanaan pelatihan tiap angkatan, tim kami mengeluarkan pengumuman mengenai namanama yang diterima menjadi peserta pelatihan. 
Metode pelaksanaan kegiatan pengabdian kepada masyarakat ini dilakukan dengan memberikan pelatihan/workshop plus praktik/latihan serta tanya jawab terkait dengan pengolahan data penelitian. Porsi kegiatan pelatihan ini dilakukan dalam bentuk teori $20 \%$ dan praktik $80 \%$.

\section{HASIL DAN PEMBAHASAN}

\section{Pelatihan Pengolahan Data Penelitian dengan Software SPSS Angkatan I}

Dari total 28 orang kuota peserta pelatihan angkatan I yang disediakan, yang mengembalikan lembar konfirmasi keikutsertaan pelatihan kepada tim sekretariat kami sebanyak 27 orang. Dari jumlah tersebut, yang memenuhi syarat untuk menjadi peserta pelatihan sebanyak 25 orang, sedangkan sisanya sebanyak 2 orang dinyatakan tidak memenuhi syarat untuk menjadi peserta pelatihan.

Namun sayangnya, dari 25 orang yang dinyatakan berhak menjadi peserta pelatihan, ternyata pada hari pelaksanaan kegiatan pelatihan, Sabtu (16/09/17), yang hadir hanya sebanyak 16 orang. Mereka mengikuti acara dari awal sampai akhir sesuai dengan jadwal yang telah ditetapkan. Sedangkan sisanya sebanyak 9 orang tidak hadir mengikuti kegiatan pelatihan. Kepada 9 orang peserta yang tidak hadir mengikuti pelatihan tersebut, kami dari tim pengabdian kepada masyarakat telah memasukkan nama mereka ke dalam daftar hitam (black list). Akibatnya mereka tidak diizinkan dan tidak dilibatkan lagi sebagai peserta atau sebagai apapun juga pada setiap kegiatan pengabdian kepada masyarakat yang kami selenggarakan.

Tindakan ini diambil karena akibat tindakan mereka kami merasa telah dirugikan. Dimana dalam persiapan yang telah kami lakukan sebelumnya termasuk dalam percetakan sertifikat telah kami siapkan kepada mereka, namun mereka tidak hadir pada hari pelaksanaan kegiatan pelatihan tanpa alasan yang jelas dan tanpa pemberitahuan sebelumnya.

Adapun nama-nama peserta yang hadir mengikuti kegiatan pelatihan disajikan dalam tabel di bawah ini.
Tabel 3. Nama-Nama Peserta yang Hadir Mengikuti Pelatihan Pengolahan Data Penelitian dengan Software SPSS Angatan II Tahun 2017

\begin{tabular}{|c|l|c|c|c|}
\hline No. & \multicolumn{1}{|c|}{ Nama } & Prodi & Fakultas & $\begin{array}{c}\text { Perguruan } \\
\text { Tinggi }\end{array}$ \\
\hline 1. & Abdullah Ahmad Badawi & S1 Agribisnis & Pertanian & UTU \\
\hline 2. & Cut Karmila & S1 EKP & Ekonomi & UTU \\
\hline 3. & Djulia Safitril & S1 EKP & Ekonomi & UTU \\
\hline 4. & Nurul Cerli Fitria & S1 EKP & Ekonomi & UTU \\
\hline 5. & Safrida Yanti & S1 EKP & Ekonomi & UTU \\
\hline 6. & Distya Utari & S1 EKP & Ekonomi & UTU \\
\hline 7. & Maulida Amanda & S1 EKM & - & STIMI Meulaboh \\
\hline 8. & Rizo Merdayani & S1 EKM & - & STIMI Meulaboh \\
\hline 9. & Cici Herawati & S1 EKP & Ekonomi & UTU \\
\hline 10. & Jerni Romauli T. & S1 EKM & Ekonomi & UTU \\
\hline 11. & Rina Zuliana & S1 EKM & - & STIMI Meulaboh \\
\hline 12. & Raidil Ali & S1 EKP & Ekonomi & UTU \\
\hline 13. & Yuliani & S1 EKP & Ekonomi & UTU \\
\hline 14. & Maryuni Elisa & S1 EKP & Ekonomi & UTU \\
\hline 15. & Wijaya Putra & S1 EKP & Ekonomi & UTU \\
\hline 16. & Susandi & S1 EKP & Ekonomi & UTU \\
\hline
\end{tabular}

Sedangkan nama-nama peserta yang dimasukkan ke dalam daftar hitam (black list) karena tidak hadir pada hari pelaksanaan kegiatan pelatihan disajikan dalam tabel di bawah ini.

Tabel 4. Nama-Nama Peserta yang Dimasukkan Dalam Daftar Hitam (black list) Karena Tidak Hadir Mengikuti Pelatihan Pengolahan Data Penelitian dengan Software SPSS Angkatan II Tahun 2017

\begin{tabular}{|c|l|l|c|c|}
\hline No. & \multicolumn{1}{|c|}{ Nama } & \multicolumn{1}{|c|}{ Prodi } & Fakultas & $\begin{array}{c}\text { Perguruan } \\
\text { Tinggi }\end{array}$ \\
\hline 1. & Cut Shinta Nabila & S1 EKP & Ekonomi & UTU \\
\hline 2. & Eriyanto & S1 Agribisnis & Pertanian & UTU \\
\hline 3. & Cut Asrina & S1 EKP & Ekonomi & UTU \\
\hline 4. & Afrina Indah Sari & S1 EKP & Ekonomi & UTU \\
\hline 5. & Selamat Ismail & S1 EKA & Ekonomi & UTU \\
\hline 6. & Desy Selviana & S1 EKM & - & STIMI Meulaboh \\
\hline 7. & Fauzi & S1 EKM & Ekonomi & UTU \\
\hline 8. & Ardimin Hartata & S1 EKM & Ekonomi & UTU \\
\hline 9. & Asmaul Husna & S1 EKP & Ekonomi & UTU \\
\hline
\end{tabular}

Untuk mengukur keberhasilan pelaksanaan kegiatan pelatihan, kami menyelenggarakan pre test dan post test. Nilai rata-rata pre test dari total 16 orang peserta pelatihan adalah 54,59 , dengan nilai minimum 33,34 dan nilai maksimum 73,34.

Sedangkan post test nilai rata-ratanya adalah 72,92, dengan nilai minimum 46,67 dan nilai maksimum 93,34. Antara nilai rata-rata pre test dan post test terjadi kenaikan sebesar 18,33. Dengan demikian dapat dikatakan kegiatan pelatihan angkatan I ini cukup berhasil dalam menambah wawasan, ilmu pengetahuan dan keterampilan bagi peserta pelatihan. Untuk kelancaran proses pelatihan, kepada peserta pelatihan dibagikan modul pelatihan masing-masing 2 (dua) buah, yaitu modul 1 dan modul 2. 
Dari hasil evaluasi akhir, kami menobatkan 2 orang sebagai peserta terbaik yaitu atas nama Djulia Safitri dan Raidil Ali, masing-masing meraih nilai post test sebesar 93,34. Keduanya merupakan mahasiswa Prodi S1 Ekonomi Pembangunan Fakultas Ekonomi Universitas Teuku Umar.

Diakhir acara kepada semua peserta diberikan sertifikat pelatihan dan kepada peserta terbaik secara khusus diberi penghargaan berupa sertifikat sebagai peserta terbaik dalam pelatihan ini.

Untuk mendapatkan umpan balik (feed back) dari peserta pelatihan, kami menyebarkan lembar evaluasi kegiatan pada akhir acara, yang terdiri dari tanggapan peserta pelatihan terhadap lima aspek yaitu: (a). pelaksanaan kegiatan, (b). manfaat kegiatan, (c). penunjang kegiatan, (d). modul pelatihan, dan (e). narasumber / fasilitator / asisten pelatihan. Terdapat 21 (dua puluh satu) item pernyataan yang harus dijawab oleh peserta pelatihan. Kepada mereka diberikan empat skala yang dapat dipilih yaitu: 1 = sangat tidak puas, $2=$ tidak puas, $3=$ puas dan $4=$ sangat puas.

Dari hasil evaluasi kami, dapat disimpulkan bahwa secara umum peserta pelatihan menyatakan sangat puas terhadap 5 indikator penilaian sebagaimana tersebut di atas. Bahkan beberapa diantaranya memberikan testimoni yang sangat positif seperti berikut ini.

Tabel 5. Testimoni Peserta Pelatihan Pengolahan Data dengan Software SPSS Angkatan I Tahun 2017

\begin{tabular}{cll}
\hline No. & \multicolumn{1}{c}{ Peserta Pelatihan } & \multicolumn{1}{c}{ Testimoni } \\
\hline 1. & $\begin{array}{l}\text { Susandi } \\
\text { (S1 EKP FE UTU) }\end{array}$ & $\begin{array}{l}\text { Kegiatan ini sangat membantu kami dalam } \\
\text { penyelesaian tugas akhir/skripsi nantinya. }\end{array}$ \\
\hline 2. & $\begin{array}{l}\text { Abdullah Ahmad Badawi } \\
\text { (S1 Agribisnis FP UTU) }\end{array}$ & Kegiatan ini sangat bermanfaa. \\
\hline 3. & $\begin{array}{l}\text { Cici Herawati } \\
\text { (S1 Manajemen STIMI } \\
\text { Meulaboh) }\end{array}$ & $\begin{array}{l}\text { Pelaksanaan kegiatan pelatihan ini sangat } \\
\text { memuaskan dan materi yang diberikan } \\
\text { sangat bagus. Juga fasilitas yang disediakan } \\
\text { panitia sangat memadai. }\end{array}$ \\
\hline 4. & $\begin{array}{l}\text { Safrida Yanti } \\
\text { (S1 EKP FE UTU) }\end{array}$ & $\begin{array}{l}\text { Kegiatan pelatihan ini sangat bermanfaat } \\
\text { karena menambah pengetahuan saya } \\
\text { mengenai pengolahan data SPSS dan } \\
\text { menambah wawasan. }\end{array}$ \\
\hline
\end{tabular}

\section{Pelatihan Pengolahan Data Penelitian dengan Software SPSS Angkatan II}

Dari total 35 orang kuota peserta yang disediakan, yang mendaftar dan mengisi lembar konfirmasi keikutsertaan pelatihan angkatan II dan menyampaikan berkas administrasi kepada tim sekretariat kami sebanyak 37 orang. Karena tingginya animo mahasiswa yang mendaftar dan secara administrasi mereka ini memenuhi syarat, maka kami berinisiatif meloloskan semuanya sebagai peserta yang berhak mengikuti kegiatan pelatihan ini. Namun demikian pada saat hari pelaksanaan pelatihan Sabtu (23/12/17), peserta yang hadir sebanyak 33 orang. Mereka mengikuti acara dari awal sampai akhir sesuai dengan jadwal yang telah ditetapkan. Sedangkan sisanya sebanyak 4 orang tidak hadir mengikuti kegiatan pelatihan.

Adapun nama-nama peserta yang hadir mengikuti kegiatan pelatihan angkatan II disajikan dalam tabel di bawah ini.

Tabel 6. Nama-Nama Peserta yang Hadir Mengikuti Pelatihan Pengolahan Data Penelitian dengan Software SPSS Angkatan II Tahun 2017

\begin{tabular}{|c|l|c|c|c|}
\hline No. & Nama Peserta & $\begin{array}{c}\text { Perguruan } \\
\text { Tinggi }\end{array}$ & Fakultas & Prodi \\
\hline 1 & Puji Silviana & UTU & Ekonomi & S1 Manajemen \\
\hline 2 & Nova Fatmawati & UTU & Ekonomi & S1 EKP \\
\hline 3 & Riska Kurnia Zahra & UTU & Ekonomi & S1 EKP \\
\hline 4 & Rika Musliani & UTU & Ekonomi & S1 EKP \\
\hline 5 & Nurhilma & UTU & Pertanian & S1 Agribisnis \\
\hline 6 & Aja Rabitah & UTU & Pertanian & S1 Agribisnis \\
\hline 7 & Dwi Ridho Mardian & UTU & Ekonomi & S1 EKP \\
\hline 8 & Yusnaidi & UTU & Ekonomi & S1 EKP \\
\hline 9 & Agusuwantri & UTU & Ekonomi & S1 EKP \\
\hline 10 & Rahmat Akbar & UTU & FKM & S1 Kesmas \\
\hline 11 & Eris Dian Novi Yanti & STIMI & - & S1 Manajemen \\
\hline 12 & Bella Santika & STIMI & - & S1 Manajemen \\
\hline 13 & Friska Devi & STIMI & - & S1 Manajemen \\
\hline 14 & Nora Ulfa & STIMI & - & S1 Manajemen \\
\hline 15 & Lela Fitriani & STIMI & - & S1 Manajemen \\
\hline 16 & Intan Juliani & STIMI & - & S1 Manajemen \\
\hline 17 & Pina Hanifah & UTU & Ekonomi & S1 EKP \\
\hline 18 & Rika Andri Yani & UTU & Ekonomi & S1 EKP \\
\hline 19 & Srilia Afrida & UTU & Ekonomi & S1 Manajemen \\
\hline 20 & Warziah & UTU & Ekonomi & S1 Manajemen \\
\hline 21 & Mailia & UTU & Ekonomi & S1 Manajemen \\
\hline 22 & Nella Agustia & UTU & Ekonomi & S1 EKP \\
\hline 23 & Mudasir & UTU & Ekonomi & S1 EKP \\
\hline 24 & Mirdayana AB & UTU & Ekonomi & S1 EKP \\
\hline 25 & Martini & UTU & Ekonomi & S1 EKP \\
\hline 26 & Melya Safhira & UTU & Ekonomi & S1 EKP \\
\hline 27 & Nur Kariza & UTU & Ekonomi & S1 Manajemen \\
\hline 28 & Fitriani & UTU & Ekonomi & S1 EKP \\
\hline 29 & Istu Widiawati & Ekonomi & S1 EKP \\
\hline 30 & Dwi Adhani & Ekonomi & S1 EKP \\
\hline 31 & Mutiah & Yuriza & Ekonomi & S1 EKP \\
\hline 32 & Ulia Anita & Ekonomi & S1 EKP \\
\hline
\end{tabular}

Sedangkan nama-nama peserta yang tidak hadir mengikuti pelatihan seperti disajikan dalam tabel di bawah ini. 
Tabel 7. Nama-Nama Peserta yang Tidak Hadir Mengikuti Pelatihan Pengolahan Data Penelitian dengan Software SPSS Angkatan II Tahun 2017

\begin{tabular}{|c|l|c|c|c|c|}
\hline No. & \multicolumn{1}{|c|}{ Nama Peserta } & $\begin{array}{c}\text { Perguruan } \\
\text { Tinggi }\end{array}$ & Fakultas & Prodi & Keterangan \\
\hline 1 & Hendri Satria & UTU & Ekonomi & S1 EKP & Sakit \\
\hline 2 & Nova & UTU & Ekonomi & S1 EKP & - \\
\hline 3 & Kurnia & UTU & FT & S1 Teknik Industri & - \\
\hline 4 & Taufik AkbarNasution & UTU & FT & S1 Teknik Industri & - \\
\hline
\end{tabular}

Untuk mengukur keberhasilan pelaksanaan kegiatan pelatihan, kami menyelenggarakan pre test dan post test. Dari 33 orang peserta yang ikut pre test dan post test, terdapat 4 orang peserta tidak mencantumkan nama pada lembaran jawaban post test, sehingga kami hanya mencantumkan nilai pre test dan post test sebanyak 29 orang peserta saja. Nilai rata-rata pre test peserta pelatihan adalah 36,55 dengan nilai minimum 20,00 dan nilai maksimum 66,67 .

Sedangkan post test nilai rata-ratanya adalah 72,42 dengan nilai minimum 26,67 dan nilai maksimum 100,00. Antara nilai rata-rata pre test dan post test terjadi kenaikan sebesar 35,86. Dengan demikian dapat dikatakan kegiatan pelatihan angkatan II ini cukup berhasil dalam menambah wawasan, ilmu pengetahuan dan keterampilan bagi peserta pelatihan. Untuk kelancaran proses pelatihan, kepada peserta pelatihan dibagikan modul pelatihan dalam bentuk paperless masing-masing 2 buah, yaitu modul 1 dan modul 2 .

Dari hasil evaluasi akhir, kami menobatkan 2 orang sebagai peserta terbaik yaitu atas nama Riska Kurnia Zahra dan Nova Fatmawati, masing-masing meraih nilai post test sebesar 100,00. Keduanya merupakan mahasiswa Prodi S1 Ekonomi Pembangunan Fakultas Ekonomi Universitas Teuku Umar.

Diakhir acara kepada semua peserta diberikan sertifikat pelatihan dan kepada peserta terbaik secara khusus diberi penghargaan berupa sertifikat sebagai peserta terbaik dalam pelatihan ini.

Untuk mendapatkan umpan balik (feed back) dari peserta pelatihan, kami menyebarkan lembar evaluasi kegiatan pada akhir acara, yang terdiri dari tanggapan peserta pelatihan terhadap lima aspek yaitu: (a). pelaksanaan kegiatan, (b). manfaat kegiatan, (c). penunjang kegiatan, (d). modul pelatihan, dan (e). profesionalitas narasumber. Terdapat 21 (dua puluh satu) item pernyataan yang harus diberikan oleh peserta pelatihan, yaitu terdiri dari aspek pelaksanaan kegiatan sebanyak 5 pernyataan, aspek manfaat kegiatan sebanyak 5 pernyataan, aspek penunjang kegiatan sebanyak 2 pernyataan, aspek modul pelatihan sebanyak 4 pernyataan dan aspek profesionalitas narasumber sebanyak 5 pernyataan.

Kepada mereka diberikan empat skala yang dapat dipilih yaitu: 1 = sangat tidak puas, 2 = tidak puas, 3 = puas dan 4 = sangat puas. Dari hasil evaluasi kami, dapat disimpulkan sebagai berikut:

1. Secara keseluruhan peserta memberikan tanggapan sangat puas terhadap terhadap aspek pelaksanaan kegiatan, manfaat kegiatan, modul pelatihan, dan profesionalitas narasumber. Hal ini dapat dimaknai bahwa kegiatan ini telah dilaksanakan dengan sungguh-sungguh, sangat bermanfaat bagi peserta pelatihan dan didukung dengan penyiapan bahan pembelajaran yang memadai serta dilatih oleh narasumber yang sangat profesional di bidangnya.

2. Sedangkan terhadap aspek penunjang kegiatan, secara keseluruhan peserta memberikan tanggapan puas. Hal ini dapat dimengerti karena masih terdapat beberapa kekurangan dalam hal sarana penunjang baik berupa tempat pelatihan maupun perlengkapan pelatihan. Kondisi tersebut disebabkan kami menggunakan ruang kelas sebagai tempat pelatihan, karena Fakultas Ekonomi UTU hingga saat ini belum memiliki ruangan khusus untuk tempat pelatihan. Demikian juga dalam hal lainnya seperti Air Conditioning (AC) tidak mendukung sehingga peserta merasa kepanasan saat mengikuti pelatihan.

Dari sudut pandang masing-masing individu peserta pelatihan, diketahui bahwa sebanyak 25 (dua puluh lima) orang atau $75,76 \%$ peserta pelatihan menyatakan sangat puas atas penyelenggaraan kegiatan pelatihan ini. Sedangkan sisanya sebanyak 8 (delapan) orang atau $24,24 \%$ peserta pelatihan menyatakan puas atas penyelenggaraan kegiatan pelatihan.

Dengan demikian dapat disimpulkan bahwa pelaksanaan kegiatan pelatihan pengolahan data penelitian dengan Software SPSS angkatan II tahun 2017 dengan sasaran program mahasiswa lintas 
perguruan tinggi dalam Kabupaten Aceh Barat Provinsi Aceh dapat dikatakan berhasil dan sukses.

Di akhir acara kami juga memintakan beberapa testimoni dari peserta pelatihan seperti disajikan dalam tabel di bawah ini.

Tabel 8. Beberapa Testimoni Peserta Pelatihan Pengolahan Data dengan Software SPSS Angkatan II Tahun 2017

\begin{tabular}{|c|c|c|}
\hline No. & Peserta Pelatihan & Testimoni \\
\hline 1. & $\begin{array}{l}\text { Nora Ulfa } \\
\text { (S1 Manajemen STIMI } \\
\text { Meulaboh) }\end{array}$ & $\begin{array}{l}\text { Pelaksanaan kegiatan pelatihan ini sangat bermanfaat } \\
\text { untuk menambah wawasan dan dapat mempermudah } \\
\text { mahasiswa saat mengolah data penelitian ilmiah. Dulu } \\
\text { kami tidak bisa menjalankan software SPSS sekarang } \\
\text { sudah bisa. Sebaiknya kegiatan seperti ini dapat } \\
\text { dilakukan lagi dimasa yang akan datang. }\end{array}$ \\
\hline 2. & $\begin{array}{l}\text { Dwi Adhani } \\
\text { (S1 EKP FE UTU) }\end{array}$ & $\begin{array}{l}\text { Saya sangat setuju adanya pelatihan ini karena kami dari } \\
\text { tidak bisa menjalankan software SPSS sekarang menjadi } \\
\text { bisa. Dan ini sangat membantu kami dalam mengolah } \\
\text { data penelitian ilmiah nantinya tanpa harus dibayar orang } \\
\text { lain lagi dalam mengolah data penelitian. Saya } \\
\text { menunggu pelatihan selanjutnya. }\end{array}$ \\
\hline 3. & $\begin{array}{l}\text { Mudasir } \\
\text { (S1 EKP FE UTU) }\end{array}$ & $\begin{array}{l}\text { Pelatihan pengolahan data dengan software SPSS ini } \\
\text { sangat penting dan sebaiknya dapat berlanjut ke } \\
\text { depannya. }\end{array}$ \\
\hline 4. & $\begin{array}{l}\text { Warziah } \\
\text { (S1 Manajemen FE UTU) }\end{array}$ & $\begin{array}{l}\text { Pelatihan ini sangat menarik karena dapat meningkatkan } \\
\text { kemampuan mahasiswa dalam memahami berbagai } \\
\text { statistika dengan sistem komputer. }\end{array}$ \\
\hline 5. & $\begin{array}{l}\text { Rahmat Akbar } \\
\text { (S1 Kesehatan Masyarakat } \\
\text { FKM UTU) }\end{array}$ & $\begin{array}{l}\text { Saya sangat senang bisa ikut pelatihan semacam ini. } \\
\text { Setelah ikut pelatihan ini saya sudah dapat melakukan } \\
\text { pengolahan data penelitian dengan software SPSS. } \\
\text { Semoga nantinya dapat mempermudah saya dalam } \\
\text { mengolah data penelitian saya. }\end{array}$ \\
\hline
\end{tabular}

Adapun bahan pembelajaran yang diberikan pada saat pelaksanaan pelatihan angkatan I dan II sebagaimana disajikan dalam tabel berikut ini.

Tabel 9. Bahan Pembelajaran pada Kegiatan Pelatihan Pengolahan Data Penelitian dengan Software SPSS Angkatan I dan II Tahun 2017

\begin{tabular}{|c|c|c|}
\hline Pukul (WIB) & Materi & Referensi \\
\hline \multirow{2}{*}{$08.00-08.30$} & Registrasi Peserta & \multirow{15}{*}{$\begin{array}{l}\text { Duwi Priyatno (2010), Paham Analisa } \\
\text { Statistik Data dengan SPSS, Jakarta, } \\
\text { MediaKom. } \\
\text { ISBN 979-877-143-5 } \\
\text { Haryadi Sarjono dan Winda Julianita } \\
\text { (2011), SPSS vs Lisrel (Sebuah } \\
\text { Pengantar, Aplikasi untuk Riset), Jakarta, } \\
\text { Salemba Empat. ISBN 978-979-061-198-6 } \\
\text { Singgih Santoso (2016), Panduan } \\
\text { Lengkap SPSS Versi 23, Jakarta, } \\
\text { Gramedia. } \\
\text { ISBN 978-602-02-8047-9 } \\
\text { Syofian Siregar (2017), Statistika Terapan } \\
\text { untuk Perguruan Tinggi, Jakarta, } \\
\text { Prenadamedia Group. ISBN 978-602- } \\
\text { 1186-93-0 }\end{array}$} \\
\hline & Pembukaan & \\
\hline $08.30-08.40$ & Pre Test & \\
\hline $08.40-10.00$ & $\begin{array}{l}\text { Pengantar Metodologi Penelitian } \\
\text { - Skala Pengukuran } \\
\text { - Transformasi Data Ordinal Menjadi } \\
\text { Interval } \\
\text { - Metode Sampling }\end{array}$ & \\
\hline $10.00-10.30$ & Uji Validitas dan Reliabilitas & \\
\hline $10.30-11.00$ & ISTIRAHAT & \\
\hline $11.00-12.30$ & $\begin{array}{l}\text { Uji Asumsi Klasik } \\
\text { 1. Uji Normalitas } \\
\text { 2. Uji Heterokedatisitas } \\
\text { 3. Uji Multikorelasi } \\
\text { 4. Uji Linearitas } \\
\text { 5. Uji Autokorelasi }\end{array}$ & \\
\hline $12.30-14.00$ & ISTIRAHAT DAN SHALAT ZUHUR & \\
\hline $14.00-14.30$ & Lanjutan Uji Asumsi Klasik & \\
\hline $14.30-15.00$ & Analisis Korelasi & \\
\hline $15.00-16.00$ & Analisis Regresi Linear Sederhana & \\
\hline $16.00-16.25$ & SHALAT ASHAR & \\
\hline $16.25-17.30$ & Analisis Regresi Berganda & \\
\hline $17.30-17.40$ & Post Test & \\
\hline $17.40-17.50$ & Penutupan & \\
\hline
\end{tabular}

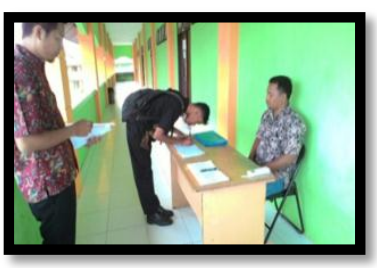

Gambar 1. Tim Pengabdian Kepada Masyarakat foto bersama peserta pelatihan angkatan I tahun 2017.

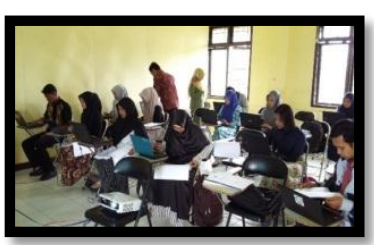

Gambar 3. Peserta pelatihan angkatan I tahun 2017 sedang serius melaksanakan praktik software SPSS

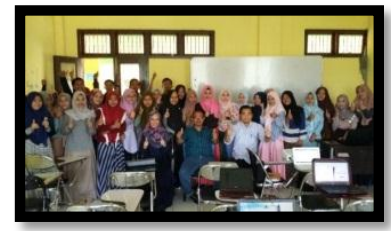

Gambar 5. Tim Pengabdian Kepada Masyarakat foto bersama peserta pelatihan angkatan II tahun 2017.

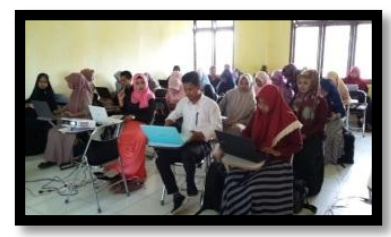

Gambar 7. Peserta pelatihan angkatan II tahun 2017 sedang serius melaksanakan praktik software SPSS.

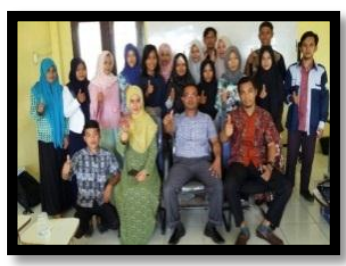

Gambar 2. Peserta pelatihan angkatan I a.n. Susandi mahasiswa Prodi S1 EKP FE

UTU sedang melakukan registrasi.

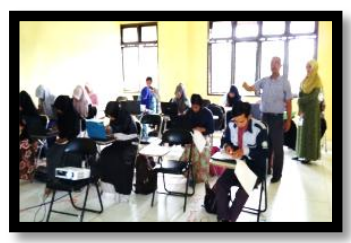
angkatan I tahun 2017 sedang serius melaksanakan praktik software SPSS

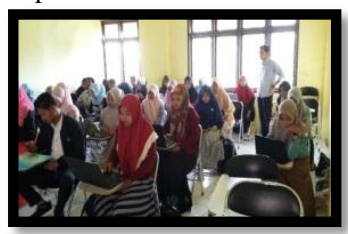

Gambar 6. Peserta pelatihan angkatan II tahun 2017 sedang serius melaksanakan praktik software SPSS.

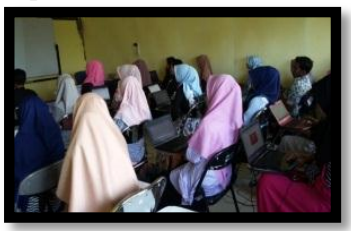

Gambar 8. Peserta pelatihan angkatan II tahun 2017 sedang serius menyimak pemaparan materi dari narasumber.
Gambar 4. Peserta pelatihan

\section{KESIMPULAN DAN SARAN}

Alhamdulillah kegiatan pelatihan pengolahan data penelitian dengan software SPSS angkatan I dan II Tahun 2017, dengan sasaran program mahasiswa lintas perguruan tinggi dalam Kabupaten Aceh Barat Provinsi Aceh, berjalan dengan lancar tanpa halangan apapun. Semua peserta antusias mengikuti acara hingga selesai dan merasakan manfaat pelatihan bagi penyelesaian tugas akhir/karya ilmiah mereka.

Pelatihan serupa dapat dilaksanakan kembali dengan peserta yang lebih banyak/luas, dan dengan topik yang sama, mengingat banyak sekali mahasiswa yang belum paham betul mengenai pengelohan data penelitian dengan software SPSS. Namun dari pihak manajemen Universitas Teuku Umar hendaknya dapat mengalokasikan dan 
menyalurkan dana pengabdian kepada tim kami ke depannya, sehingga kendala pendanaan yang kami hadapi dapat teratasi. Patut dimaklumi bahwa kegiatan semacam ini adalah salah satu langkah nyata dalam mencerdaskan kehidupan anak bangsa, dan secara khusus sangat bermanfaat bagi mahasiswa dalam penyelesaian tugas akhir sebagaimana testimoni yang telah disampaikan oleh mereka.

\section{REFERENSI}

Duwi Priyatno (2010), Paham Analisa Statistik Data dengan SPSS, Jakarta, MediaKom. ISBN 979877-143-5
Haryadi Sarjono dan Winda Julianita (2011), SPSS vs Lisrel (Sebuah Pengantar, Aplikasi untuk Riset), Jakarta, Salemba Empat. ISBN 978-979061-198-6

Singgih Santoso (2016), Panduan Lengkap SPSS Versi 23, Jakarta, Gramedia.

ISBN 978-602-02-8047-9

Syofian Siregar (2017), Statistika Terapan untuk Perguruan Tinggi, Jakarta, Prenadamedia Group. ISBN 978-602-1186-93-0 